\section{OP-217多発性輁胞腎に対する腹腔鏡下㤟胞開空 術の臨床的検討}

\author{
杏林大学医学部泌尿器科学 \\ 小田金 哲広, 榎本 香織, 藤田 直之, 林 建二郎, \\ 板谷 直, 原 秀彦, 多武保 光宏, 宍戸 俊英, \\ 桶川 隆嗣, 奴田原 紀久雄, 東原 英二
}

【目的】多発性囊胞腎患者の腹部症状及び感染症状の軽減 目的として腹腔鏡下霊胞開空術を 7 例 9 腎に対して施行し たので、臨床的に検討した。【対象・方法】1999年 2 月か ら 2009 年 7 月に施行した多発性囊胞腎に対する腹腔鏡下 囊胞開空術 7 例 9 腎（両側同時手術 2 例）。手術は後腹膜 アプローチ・3ポートにて行ったが、1例は大きな囊胞の 位置が内側に位置していたため、経腹的アプローチにて施 行した。囊胞内容を穿刺吸引後に、囊胞壁を切除し十分に 開空した。【結果】平均年齢 58.9 歳。男性 4 例、女性 3 例。 6 例は腹部圧迫症状に対して行い、1 例は囊胞内感染に伴 う発熱が持続したためドレナージ目的に施行した。後腹膜 アプローチは 6 例 8 腎、経腹的アプローチは 1 例 1 腎であっ た。左右は右 2 例、左 3 例、両側 2 例であった。平均手術 時間は 207 分で、内容液の吸引量は平均 $620 \mathrm{ml}$ であった。 3 例 4 腎に関しては術前後にMRIにて腎の体積を計測し た。1腎あたりの術前体積は平均 $2079 \mathrm{ml}$ 。術後の体積減 少は平均 $565 \mathrm{ml}$ であった。ほほ全例において、術後は腹 部症状の改善がみられ、感染症例に関しては炎症反応の改 善及び解熱を認めた。【結論】多発性囊胞腎患者の自覚症 状改善目的として、腹腔鏡下嚢胞開空術は有効な手術法で あると考えられた。

\section{OP-218 名古屋第二赤十字病院泌尿器科における 体腔鏡下腎摘出手術の初期経験}

\footnotetext{
名古屋第二赤十字病院泌尿器科 ${ }^{1)}$, 東京女子医科大学泌尿 器科2), 中京病院泌尿器科 ${ }^{3)}$, 名古屋大学泌尿器科 ${ }^{4)}$

錦見 俊徳 ${ }^{1)}$, 近藤 恒德 ${ }^{2}$, 吉田 真理 ${ }^{11}$, 塩田 隆子 ${ }^{1)}$, 石田 亮 ${ }^{1)}$, 山田 浩史 ${ }^{12}$, 横井圭介 ${ }^{11}$, 小林 弘明 ${ }^{1)}$, 絹川 常郎 ${ }^{3)}$, 後藤 百万 ${ }^{4)}$

【目的】名古屋第二赤十字病院泌尿器科では 2007 年 6 月よ り体腔鏡下腎摘出手術を本格的に開始し、2009 年 8 月ま での約 2 年間に 26 例の体腔鏡下腎摘出手術を施行した。 その初期経験について報告する。【対象と方法】2007 年 6 月から 2009 年 8 月までに体腔鏡下腎摘出手術を施行し た 26 例を対象とした。男性 17 例、女性 9 例、平均年齢 は 63.6 歳 $(34 \sim 85$ 歳)。患側は右 14 例、左 12 例。術式 は根治的腎摘出手術が 21 例、下腹部開腹手術併用腎尿管 全摘膀胱部分切除手術が 5 例であった。【結果】体腔鏡手 術時間中央値は 266 分 (197 479 分)、出血量中央値は $22.5 \mathrm{ml}(5 \sim 200 \mathrm{ml})$ 。開腹手術に移行した症例はなく、合 併症は術後出血を透析患者の 1 例に認めた。病理組織診 断は腎細胞癌が 18 例 (clear cell：15 例、Chromophobe： 2 例、papillaly : 1 例)、尿路.上皮癌が 5 例、oncocytoma が3例であった。【結論】体腔鏡下腎摘出手術は低侵襲 かつ比較的安全にな術式と考えられる。しかし、一方で oncocytoma 3 例認め、腎部分切除手術の選択等その適 応については更なる検討が必要と考えられた。
}

\section{OP-219 肥満腎癌症例に対する後腹膜鏡下腎全摘 除術の臨床的検討}

\section{仙台社会保険病院泌尿器科 ${ }^{1)}$, 仙石病院泌尿器科 ${ }^{2)}$}

工藤 貴志 ${ }^{1)}$, 竹内 晃 ${ }^{1)}$, 松浦 忍 ${ }^{1)}$, 相沢 正孝 ${ }^{1)}$, 庵 谷 尚正 ${ }^{1)}$, 折笠 精—2

【目的】肥満の有無による手術成績の差異を検討した。【対 象】 2005 年 1 月から 2009 年 8 月（4年 8 ケ月間）に当科 で後腹膜鏡下腎全摘除術を施行した腎癌症例 118 例を対象 とした。男性 84 例、女性 34 例、年齢 29-85才（中央値 62 才)。臨床病期 Tla_76 例、T1b_41 例、T3b_1 例。対象を BMI で 2 群に分け、BMI が 25 以上の症例を「肥満群」(n= $50: 25.0-41.6 \mathrm{~kg} / \mathrm{m}^{2}$ 、中央值 $\left.27.5 \mathrm{~kg} / \mathrm{m}^{2}\right) 、 25$ 未満を「正常 群」(n=68:16.2-24.8 kg/m²、中央值 $\left.22.4 \mathrm{~kg} / \mathrm{m}^{2}\right)$ として 比較検討した。【結果】肥満群の手術時間 91-292 分 (中央 值 186 分)、出血量 $0-783 \mathrm{ml}$ (中央値 $186 \mathrm{ml}$ )、摘出腎重量 $210-760 \mathrm{~g}$ (中央值 448g)。正常群の手術時間 77-273 分 (中 央值 157 分)、出血量 $0-804 \mathrm{ml}$ (中央値 $17 \mathrm{ml}$ )、周囲脂肪組 織を含む摘出腎重量 120-700（中央值 280g)。肥満群で有 意に手術時間が長く、摘出腎重量が重かった。出血量に有 意差を認めなかった。正常群の 1 例で腎癌の結腸浸潤のた め開腹し合併切除したが、その他で開放手術に移行した症 例はなかった。【考察】肥満腎癌症例に対して後腹膜鏡下 腎全摘除術を安全に施行できた。創の小さい鏡視下手術は 肥満症例においても良い適応と考える。

\section{OP-220 透析腎癌症例に対する後腹膜鏡下腎摘除 術の臨床的検討}

\author{
仙台社会保険病院泌尿器科 ${ }^{11}$, 仙石病院泌尿器科 ${ }^{2)}$ \\ 松浦 忍 ${ }^{1)}$, 工藤 貴志 ${ }^{1)}$, 竹内 晃 ${ }^{12}$, 相沢 正孝 ${ }^{1)}$, \\ 庵谷 尚正 ${ }^{1)}$, 折笠 精一 ${ }^{2)}$
}

【目的】透析腎癌症例に対する後腹膜鏡下腎全摘除術の手 術成績を検討した。【対象】 2005 年 1 月から 2009 年 8 月 (4 年 8 ケ月間) に当科で後腹膜鏡下腎全摘除術を施行した透 析腎癌症例 52 例（以下、HD 群）を対象とした。男性 42 例、女性 11 例。年齢 39-79才 (中央值 60 才)。手術まで の透析期間は 9-368 ケ月 (中央值 163 ヶ月)。今回の検討 にあたり同時期に後腹膜鏡下腎全摘除術を行った非透析腎 癌症例 118 例（以下、非 HD 群）を比較対照データとして 用いた。【結果】HD 群の手術時間 78-297 (中央值 174 分) 、 出血量 0-945 (中央值 43ml)、周囲脂肪組織を含む摘出腎 重量 115-1900g（中央値 420g）。非 HD 群では手術時間 77292 (中央值 165 分)、出血量 $0-804 \mathrm{ml}$ (中央值 $30 \mathrm{ml}$ )、摘 出腎重量 $120-760 \mathrm{~g}$ （中央值 $356 \mathrm{~g}$ ）。両群間の手術時間・出 血量・摘出腎重量に有意差を認めなかった。HD 群の腎動 脈石灰化著明な 1 例で腎動脈結紮時に血管壁を損傷したた め開放手術に変更した。非 HD 群の 1 例では腎癌の結腸浸 潤のため開腹の上で合併切除した。その他で開放手術に移 行した症例はなかった。【考察】透析症例と非透析症例の 手術成績に有意差を認めなかった。たたし、透析症例では 腎動脈の石灰化が強く脆弱な場合が多く、腎血管の処理に あたってはより慎重な操作が必要である。 